\title{
Attitudes of Executives towards Electronic Human Resource Management: A Case Study ABC Hotel
}

\author{
Kitimaporn Choochote, \\ Faculty of Interdisciplinary Studies, Khon Kaen University, Thailand
}

\begin{abstract}
.
The purposes of this research were to study the attitudes of executives towards introduction of Electronic Human Resource Management (E-HRM) in ABC hotel. This research is a qualitative research investigated from academic documents and in-depth interviews. The results found that chief executives believed that it could be adapted to use only in certain parts and other parts did not need to invest because of some systems already had good and appropriate management. Middle executives believed that it could be used in some parts of the hotel such as human resource department that used it in recruitment process. Likewise, most of lower executives agreed, however, if staff had insufficient knowledge on its systems or devices, implementation would be difficult.
\end{abstract}

Keywords: e-HRM, human capital, hotel executives, case study

\section{Introduction (TNR 14pt., bold)}

In the past, the human resources department recorded information in document forms which was difficult to store and search as well as there were many steps, causing it took a long time. Currently, technology has changed more and more rapidly, the companies therefore have to adopt and develop their technology, especially human resource management that plays an important role in the companies such as job interview, employee recruitment, leave and resignation, etc. by applying it in various parts of organization as a result the work is more efficient, able to use technology for managements and administrations such as recording data in database for searching easily and it does not need to be a complicated document with many steps as same as in the past, resulting it is convenient, quick for searching and reduce unnecessary steps.

Advantages of implementing the Electronic Human Resource Management: E-HRM in organization are: 1) Increase the efficiency of Human Resource Management (HRM), reduce working time, especially for works with a lot of forms and documents, work more convenient and easier; 2) Staffs can easier and more convenient access to information at all times; 3) Systematic database management assists executives to get the right information quickly, increases the efficiency of decision making and administration of executives, enhances competitiveness of business, and is also preparing to support changing of business in the future; 


\title{
$11^{\text {th }}$ International Conference on Modern Research in
} MANAGEMENT, ECONOMICS and ACCOUNTING

\author{
18-20 December, 2020 Oxford, United Kingdom
}

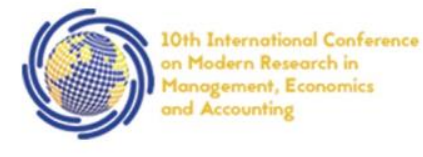

and 4) E-HRM is a system that involves with employees at all levels. Data is inked in Real Time manner which this system will allow all employees to participate in personnel management, for example, all employees can access to update their information, such as recording a new address in case of they change their address, record a leave letter for request an approval from supervisor, requesting to see their own salary, printing the salary certificate by themselves, browsing their training history and supervisor of each department can also update their information, including supervise his subordinates via the E-HRM system by himself such as leave approval, subordinate's performance appraisal, viewing subordinate's information, and recording subordinate's salary increases and adjustments, etc.

Most importantly, the human resource processes will be changed, especially reduction of documentation work. The human resource work therefore can be more managed, such as planning, supervising the personnel development, etc. The role of human resource department will more focus on strategic work.

\section{Literature Review}

\subsection{Human resource management}

Human resource management in current business world is more growing and expanding. Personnel frameworks therefore need to be expanded and developed in accordance with the aforementioned changes. Most scholars did not consider personnel in organization as an assigned shot caller, in the new role, personnel also are a resource of organization or called "human capital", which participate, promote and support the works of organization to proceed efficiently and effectively, resulting organization has a success, growth and progress. For this reason, human resource management is accepted and important to organization.

\subsection{Electronic Human resource management processes}

E-HRM processes: The process for developing human resource management into the E-HRM system, starting from the policy formulation process to be clear and planning for implementation by considering all work processes of human resource management and designing system to meet the future work that can be developed and solved problems. Factors for considering the current system improvement, including introduction and selection of system in work is response ability of system to the human resource management of organization that can plan and use the work plan. Electronic human resource management processes are as follows:

1) Job application such as downloading and submitting an online application form, and making appointments;

2) Employee systems such as the history of employee's information, leave and downloading various forms;

3) Additional learning and training such as training information and downloading information from training; 
$11^{\text {th }}$ International Conference on Modern Research in MANAGEMENT, ECONOMICS and ACCOUNTING

\section{8-20 December, 2020 Oxford, United Kingdom}

4) Assessments such as online self-assessment and supervisors can assess subordinates via online;

5) Organization's basic information management such as details, responsibilities and duties of each department;

6) Advantages such as viewing welfare information via online;

7) Payroll systems, for example, viewing current salary;

8) Skill development such as exchange of ideas within organization and clear assignments on a daily basis;

9) Continuous putting the work plans, such as determining directions and goals of organization;

10) Position management, such as career growth and aptitudes.

\subsection{Attitude}

Attitude means feelings, thoughts, or beliefs and tendency to express one's behaviour. It is a reaction by estimating whether likes or dislikes, affected to positive or negative response to a person, thing, and situation in that person's environments. This attitude can be learned or managed using their experiences and known or interpreted from what someone says informally or from formal surveys or their behaviour.

\subsection{ABC Hotel}

ABC Hotel was located in front of the Beach. At the beginning, it was bungalows and later, it is continuous developed with total period of establishing of more than 30 years.

\section{Research Objective}

To study the attitudes of executives towards Electronic Human Resource Management in ABC Hotel.

\section{Research Methodology}

\subsection{Population and samples}

The population was 21 executives of ABC Hotel dividing into 3 levels consisted of 1 senior executive, 6 middle executives, and 14 lower executives (this study used the population as the samples, namely there were 21 samples.)

\subsection{Research instruments}

Instruments used in this study were a structured interview obtained from researching academic documents which was an important guideline for creating the tools used for collecting data which designed structure of the questions as an open-ended interview, resulting in flexible question by conducting the in-depth interviews. 
$11^{\text {th }}$ International Conference on Modern Research in MANAGEMENT, ECONOMICS and ACCOUNTING

\section{8-20 December, 2020 Oxford, United Kingdom}

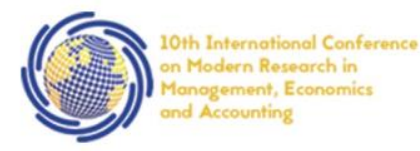

\subsection{Data collection}

In order to find out the conclusions, the author played an important role in data collection by recording, observation and interview.

\subsection{Data analysis and presentation of results}

This study was a qualitative research which determined to collect data using in-depth interview by the author had asked for cooperation from organization in order to interview the samples by observation and recording data.

\section{Conclusion}

From the study of attitudes of executives at each level towards the introduction of E-HRM in $\mathrm{ABC}$ hotels were as follows:

1. Chief executives agreed with the introduction of E-HRM in organization, due to technology were adapted to human resource department to be more convenient and faster.

2. Middle executives agreed with introduction of E-HRM in organization because of it was a modern technology with convenience and able to access various information easily such as checking salary information which would be direct connected with employee information, and online training without wasting time and other expenses, etc.

3. Lower executives agreed with introduction of E-HRM in organization due to currently, technology has developed rapidly as a result it is easier to communicate and submit information to each other. For the hotel, most data were collected in document forms, if this system is implemented in organization; it will reduce the work process and can check various information via online such as employee history, welfare information, etc. It can be implemented in some parts of hotel, such as job application process, allowing applicants to fill out an application form and submit the proofs of application via online, without wasting time and expenses for going to apply for jobs. However, it should not be implemented in some parts because of it is difficult to control such as online job interviews because of they are unable to see personality of applicants how their characteristics look like, they are appropriate for a job position or not, and employees can easily take a leave via online, causing supervisor does not know when employee take leave and cannot find other employees to substitute for on time. There was 1 lower executive disagreed with introduction of E-HRM because of he had some experience on use of E-HRM, he found that the system was unstable and believed that if it is used, it may delay the work.

\section{Discussion}

The study found that chief executives believed that ABC Hotel could apply E-HRM only in some parts while another parts did not need to invest because of some systems were already well managed and E-HRM had both advantages and disadvantages because of some systems in hotels could be adapted, resulting they more efficient and reduce unnecessary steps, while another systems did not need to be adjusted because of it may not be worth to invest and some 


\title{
$11^{\text {th }}$ International Conference on Modern Research in
} MANAGEMENT, ECONOMICS and ACCOUNTING

\author{
18-20 December, 2020 Oxford, United Kingdom
}

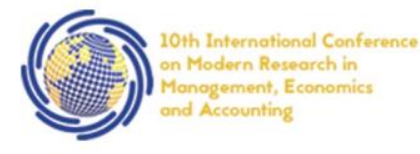

staffs did not have computer knowledge, if it is applied, employees must be trained and the applied systems may not be worth to invest and waste time.

Middle executives believed that $\mathrm{ABC}$ hotel use assessments via document forms rather than via online because of face-to-face assessments are better, allowing employees to know how they work and what they should improve. The annual assessment of $\mathrm{ABC}$ hotel will be carried out for twice a year, if the system is introduced, it will not be worth. ABC hotel used assessment in document form, not online assessments and some staffs did not have technological knowledge, they therefore cannot be assessed via online and saw that the EHRM could be used only in some parts of hotel, such as human resource department that used it in job application process, consisting of filling out a job application form, submitting proofs and application form via online, online interviews, etc. Online interviews can be used dividing into two parts: the first for chief executives and the second for middle and lower executives. Both interviews should be carried out simultaneously via both online and face-to-face method. It should not be used with the leave which should direct report to supervisor, and the assessments which should be carried out via face-to-face method, as well as the training which should carried out via meetings more than online because of participants can easier and clearer discuss, exchange and communicate together in the meetings than listening via online.

Most of lower executives agreed with the use of E-HRM, however, if staffs had insufficient knowledge on its system or supported devices, adaptation will be difficult and inconvenient, as well as it may not be worth to invest. It will be better if there is training for staffs and sufficient devices before the E-HRM has been practically implemented.

\section{Suggestions for future research}

The attitude of hotel staff should be studied to compare with the attitudes of hotel executives and determined its relationship and consistency.

\section{References}

Bassili JN. (2008). Attitude strength. See Crano \& Prislin 2008, pp. 237-60

Bates, T. (1990). Entrepreneur Human Capital Inputs and Small Business Longevity. The Review of Economics and Statistics, 72(4), pp. 551-559.

Briñol P, Petty RE, McCaslin MJ. (2009). Changing attitudes on implicit versus explicit measures. In Attitudes. Insights from the New Implicit Measures, ed. RE Petty, RH Fazio, P Briñol, pp. 285-326. New York: Psychol. Press.

Crossan, M. M., \& Apaydin, M. (2010). “A multi-dimensional framework of organizational innovation: a systematic review of literature. Journal of Management Studies," vol.47 (6), pp.1154-1191.

Florkowski, G. W., \& Olivas-Lujan, M. R.(2006). "The diffusion of human-resource information-technology innovations in US and non-US firms," Personnel Review, vol.35 (6), 684-710. 
$11^{\text {th }}$ International Conference on Modern Research in MANAGEMENT, ECONOMICS and ACCOUNTING

\section{8-20 December, 2020 Oxford, United Kingdom}

James S. Coleman. (1988). "Social Capital in the Creation of Human Capital", The American Journal of Sociology. vol 94. pp. 95-120.

Nemanja Berber et al., (2018). "Electronic Human Resource Management (e-HRM): A New Concept for Digital Age," STRATEGIC MANAGEMENT, vol. 23(2), pp. 22-32.

Panayotopoulou, L., Vakola, M., \& Galanaki, E. (2007). "e-HR adoption and the role of HRM: evidence from Greece,” Personnel Review, vol.36(2), pp. 277-294.

Stone, D. L., Lukaszewski, K. M., Stone-Romero, E. F., \& Johnson, T. L. (2013). "Factors affecting the effectiveness and acceptance of electronic selection systems," Human Resource Management Review, vol. 23(1), pp. 50-70.

T. Bondarouk et al., (2012). Electronic HRM in Theory and Practice: Advanced Series in Management, Emerald Publishing, Bingley, UK. 